\title{
Honouring The Honourable William A. Stevenson
}

\author{
The HonOurable Justice Russell Brown*
}

Thank you for that very kind introduction, and my thanks also to the Editorial Board of the Alberta Law Review for the invitation to speak this evening. I think those of you who know me well will know how very happy I am not only to be back home in Edmonton - a place I just don't see very often anymore — but also among friends — former students, faculty colleagues, and colleagues at the bar and bench.

And I am particularly pleased to speak at this event, associated as it is with the Alberta Law Review. The relationship between the judiciary (and, certainly, the appellate judiciary) and legal scholars is sometimes notoriously fraught with tension or, at best, resembles ships passing in the night.

But the relationship is one of mutual benefit.

On one side of the ledger, judges are heavy consumers of legal scholarship. And it is not surprising that we are. Many law review articles contain arguments and opinions pertinent to the choices that judges must make, and lawyers commonly refer to such works in the written and oral submissions they present to us. Indeed, some law review articles are direct exhortations to judges about how to decide cases expected to come before them.

Which brings me to the other side of the ledger. While judges are heavy consumers of legal scholarship, they are also major producers of raw material for legal scholarship. Especially when we on the courts get it wrong (which, I gather we almost always do to some degree).

But law reviews do more, of course, than edify judges about the errors of their ways. The Alberta Law Review, like its predecessor the Alberta Law Quarterly, serves the public interest by disseminating the considered views of law students and academic lawyers, thereby educating the bench, the bar, and the public they serve about what the law is, where the law is going, and where (in their judgment) the law should be going, and why.

Even when - and I know this is sometimes the case - the law review author thinks he or she is writing to only about 20 other academic lawyers scattered around the globe, the ricochet effects of the scholarship contained in the Alberta Law Review are difficult to overstate. I can tell you that your titles are circulated regularly to all the judges on my Court, and I suspect most, if not all of us, look them over to see if there are new insights into old conundrums awaiting our attention.

The far-reaching impact of a single law journal article is something that one of the Alberta Law Review's founders, Justice William Stevenson, knew. And I am delighted to see his daughter Vivian here this evening. 
As a law student, lawyer, and as a law professor, he generated legal scholarship. As a law student, lawyer, law professor, and judge, he consumed legal scholarship. And, as a lawyer, a trial judge, and appeals judge, he generated a lot of that raw material of which legal scholarship is made.

The contributions of Justice Stevenson - Alberta's greatest legal all-rounder - are I think worthy of substantial reflection by those of us who concern ourselves with the law, with legal method, and with judicial writing — certainly much more reflection than might be inspired by a single speech at a reception. So let me be clear - all I can do is scratch the surface this evening. Justice Stevenson's contribution to the law of Alberta and the law of Canada merits much more extensive reflection and discussion. But I hope this represents a start.

William Alexander Stevenson was born in Edmonton in 1934. He was the only child of Alexander Lindsay Stevenson and Eileen Harriet Burns. He attended Eastwood School and, for a time, worked summers at Crescent Motors - a large filling and repair station on Stony Plain and 140 Street. From 1952, he attended the University of Alberta, graduating in 1957 with a Bachelor of Arts and a Bachelor of Laws - along with, for good measure, the Horace Harvey Gold Medal in Law. During his studies, he was close to Dr. Alexander Smith, QC, one of the finest academic lawyers of his time who, I understand, thought the young Bill Stevenson to be the best student the law school ever had.

He articled to, then (after his call to the Bar of Alberta in 1958) practised with, the great William Morrow, later Justice Morrow of the Northwest Territories Court and, even later, the Court of Appeal of Alberta. Together, at Morrow, Morrow \& Reynolds, now Reynolds Mirth Richards \& Farmer LLP, they were counsel on the last case from Canada to be appealed to the Judicial Committee of the Privy Council - Ponoka v. Calmar Oils - the story of which is, as it happens, recounted in an issue of the Alberta Law Review. ${ }^{1}$

Around this time, in July 1961, Justice Stevenson — I realize he wasn't a "justice” yet, but I have never known him as anything else, so "Justice Stevenson" he will be throughout my talk - married Patricia. Four children followed, and today he enjoys four grandchildren as well.

Justice Stevenson's legal practice involved some solicitor's work, but focused primarily on litigation, including personal injury work for plaintiffs. In that area of law, he is reliably reported as having inherited Bill Morrow's love of undercharging the client.

From 1963, he was a lecturer at the Faculty of Law at the University of Alberta and, from 1968 to 1970, he was a full-time member of the Faculty, after which he continued to teach part-time for another 15 years. Consistent with this background in legal education, Justice Stevenson was also a founder of the National Judicial Institute and is one of only two people who hold a distinguished honorary membership on its Board of Governors, the other being the Honourable Frank Iacobucci. And, he was founder and chair of, and a frequent lecturer for, the Legal Education Society of Alberta. 
In 1975, he was appointed to the District Court of Alberta. This was at a time when the District Court was receiving Alberta's most able lawyers into its ranks - the likes of Justices Kerans, Hetherington, Wachowich, and Haddad — and Justice Stevenson. With the merger of the courts in 1979, he became a Queen's Bench justice. In 1980, he was elevated to the Courts of Appeal of Alberta and the Northwest Territories, where he served for ten years before being appointed to the Supreme Court of Canada. He stepped down from that Court in 1992 and later that year was honoured by the University of Alberta with an honorary doctorate of laws.

In 1999, when the building housing the Alberta Law Review was officially named for Justice Stevenson, his longtime friend, co-author, and former colleague, Justice Jean Côté, wrote a short biography of Justice Stevenson. One passage in particular struck me, and I share it with you now:

In a very partisan age, Bill's thoughts, arguments, and writing were never shaped by partisan considerations, pre-judgments, dogma, social theory, or politicized views.

An important reason for that is his distrust of theory which is unrelated to experience.

Never has any lawyer or judge more fully integrated theory with fact, teaching with practice, than did Bill Stevenson. His statements of claim, examinations for discovery, and trials made full use of his very articulated knowledge of the law. Every talk which he gave to a law student, whether privately or to a big class, was full of practical examples and shaped by actual experience. ${ }^{2}$

I was struck by this passage when I read it, because I had by then read through about 60 of Justice Stevenson's decisions at all levels of court in anticipation of this evening. And so I immediately recognized the essential truth of this observation. Justice Stevenson's distrust of theory that is unrelated to experience encapsulates much of his judicial writing.

One prominent example of this is his dissent at the Supreme Court in Canson Enterprises Ltd. v. Boughton \& Co. ${ }^{3}$

In Canson, the appellant Canson and the respondent Peregrine had agreed to purchase and develop some real property on the recommendation of the respondent, Treit. However, Treit had arranged an intervening flip of the property, resulting in the appellants paying $\$ 115,000$ more for the property than necessary - all of which was a kickback for Treit and Peregrine. Peregrine knew about the flip but did not disclose its existence to Canson.

A Vancouver lawyer acted as solicitor on all these transactions, including the final purchase by Canson and Peregrine. To conceal from Canson the flip and the secret profit, he documented the transaction in question as a transfer from the original vendor directly to the purchasers, leaving out the flip. 
Ultimately, the development came a cropper, but for completely unrelated reasons. Due to the negligence of the soil engineers whom Canson had hired to analyze the property, the planned development was not feasible. Ultimately, Canson's lender foreclosed, resulting in a shortfall of more than $\$ 1,000,000$ to Canson. It was around then that Canson learned of Peregrine's secret kickback.

Canson sued Peregrine, the lawyer, and his law firm for deceit and breach of fiduciary duty. The claim was based on the conceded fact that, but for the lawyer's failure to disclose the land flip and the resulting secret profit, Canson would not have purchased the property and therefore would not have suffered the losses from its development caused by the negligence of the soil engineers.

In other words, the claim sought to impose liability upon the defendants for initiating the chain of events which culminated in the failure of the project, notwithstanding that they had neither hired nor had authority over the soil engineers.

The trial judge absolved the lawyer of liability in deceit, but imposed liability for breach of fiduciary duty and awarded damages on the same basis as if liability for deceit had been imposed. The Court of Appeal dismissed Canson's appeal, and Canson appealed further to the Supreme Court. It also dismissed the appeal.

For the majority, Justice La Forest conceded that the claim in deceit would fail at common law, based on principles of causation and remoteness. At the same time, he also acknowledged that a successful action in deceit would have resulted in a more generous award for Canson, since damages would not be limited to losses that were foreseeable. But this did not prevent Justice La Forest from awarding that same measure of damages in a case of breach of fiduciary duty, "barring different policy considerations underlying one action or the other," he said, "I see no reason why the same basic claim, whether framed in terms of a common law action or an equitable remedy, should give rise to different levels of redress."

Citing the "fusion" of law and equity, he advanced a theory that equity "should ... borrow from the experience of the common law," must be "flexible," and must "be moulded to meet the requirements of fairness and justice in specific situations."

For Justice Stevenson, this was all just a bit much. He first threw some facts - as if it were a glass of ice-cold water — on the majority's theoretical musings about identical "policy considerations" governing deceit and breach of fiduciary duty. The facts of this case, he said, belie that claim. ${ }^{6}$ The lawyer had nothing to do with the selection of the soil engineers, did not control them, and had nothing to do with their meeting or failing to meet contractual or bonding obligations. Their negligence was, plain and simple, so remote - that is, unrelated to and independent from the lawyer's misconduct — that it should not be attributed to him. Theory must bend to fact. 
Then he poured another glass of cold water on the part of the majority's reasoning grounded in "fusion" of law and equity.

"I do not think," wrote Justice Stevenson, "that the so-called fusion of law and equity has anything to do with deciding this case." Now, that might to some of you seem a bold statement. Until you read the next statement which, to my mind, is irrefutable, unanswered by the majority, and perhaps — just perhaps — should have been determinative. "If it did," Justice Stevenson continued, "the rules of equity would prevail." ${ }^{\text {In }}$ other words, equity trumps law. It is not the other way around. The equitable remoteness rules governing breach of fiduciary duty should prevail over the common law no-remoteness rule governing deceit. And no theory can overcome that basic, doctrinal fact.

Canson was, of course, an example of new theory giving way not only to the facts of the case, but also the fact of longstanding doctrine. This sort of thing always triggered a cautious response from Justice Stevenson. But the converse is also true. That is, Justice Stevenson was also suspicious of old theory that seemed inconsistent with experience.

In R. v. L. (W.K.), the accused was charged with sexual offences against his two daughters and a stepdaughter, said to have occurred between 1957 and 1985. The first complaint was made in $1986 .^{9}$

In his trial opening, the accused moved for a stay on the basis that it was contrary to the principles of fundamental justice to be charged after so long a period of time had elapsed and to be so charged on uncorroborated evidence. The trial judge granted the stay, finding that the complainants' explanations for the delay were "ludicrous" and "specious." 10 More particularly, he found it incredible that the complainants, who had remained for many years under their parents' care, had not complained earlier.

The Court of Appeal set aside the stay, stating that the trial judge had erred in determining the complainants' credibility without a viva voce hearing. ${ }^{11}$

For the Supreme Court, Justice Stevenson dismissed the appeal. In reasons that preceded Ewanchuk v. The Queen ${ }^{12}$ by eight years, he cited the 1984 Badgley Report on Sexual Offences against Children and Youths as revealing the high frequency of non-reporting, incomplete reporting, and delay in reporting sexual offences. ${ }^{13}$ After reviewing excerpts from that report, he concluded:

For victims of sexual abuse to complain would take courage and emotional strength in revealing those personal secrets, in opening old wounds. If proceedings were to be stayed based solely on the passage of time

Ibid at 590 .

Ibid.

[1991] 1 SCR 1091 [L(WK)].

Ibid at 1095-96, citing Co Ct (New Westminster), No X018265 (9 September 1988).

51 CCC (3d) 297 (BCCA).

[1999] 1 SCR 330.

Canada, Department of Justice, Sexual Offences Against Children: Report of the Committee on Sexual Offences Against Children and Youths, by Robin F Badgley (Ottawa: Department of Justice, 1984). 
between the abuse and the charge, victims would be required to report incidents before they were psychologically prepared for the consequences of that reporting. ${ }^{14}$

He went on:

Establishing a judicial statute of limitations would mean that sexual abusers would be able to take advantage of the failure to report which they themselves ... caused. This is not a result which we should encourage. ${ }^{15}$

What this tells us, I think, is that Justice Côté's observation of Justice Stevenson's distrust of theory that is unrelated to experience is closely linked — Justice Côté saw it as causally linked - to another quality that one cannot help discerning in the judgments of Justice Stevenson: being, their eschewing of dogma, or even of mere policy preference that would suggest predisposition or prejudgment. Justice Stevenson was the very model of the neutral, dispassionate, open-minded arbiter - whether he was resisting new untested enthusiasms, such as the doing away with sound doctrinal distinctions between common law torts and equitable actions, or old groundless prejudices about how a sexual assault complainant should be expected to conduct herself. He was not a Cardozo-like figure with statements of policy and prejudice in his head, looking for a place to plant them.

Indeed, Justice Stevenson valued political neutrality so deeply that some of his colleagues at the Supreme Court would have said he did so to a fault. And, on this point, time does not permit me tonight to discuss his dissent in Osborne v. Canada (Treasury Board), ${ }^{16}$ in which Justice Stevenson would have upheld a provision of the Public Service Employment Act, ${ }^{17}$ which prohibited partisan expression and activity by federal public servants.

Agree or disagree with it, I think it is worth reading as an account of the importance of neutrality to the public interest. And it was entirely fitting that he be the judge to make that case, as he was - and, again, I say this having recently read about 60 of his judgments the very personification of that virtue as a judge.

I think any remarks on Justice Stevenson are incomplete without at least some brief discussion about judicial methodology. In Canadian National Railway Co. v. Norsk Pacific Steamship Co., the defendant's negligently operated barge struck a railway bridge owned by Public Works Canada. ${ }^{18}$ This forced the four users of the bridge to reroute their railcars, causing them to suffer what is called relational economic loss (in that their economic loss was relational to the damage to Public Works' bridge). Three of the four railway users, including the CNR, which was the principal user, sought compensation for their rerouting expenses.

The lead judgment was a dissent by Justice La Forest, which sought to distinguish relational economic loss from other economic and non-economic claims on what he saw as the policy concern for pragmatism and certainty in the law and in judicial law-making. The

L(WK), supra note 9 at 1101 .

Ibid.

[1991] 2 SCR 69.

RSC 1985, c P-32.

[1992] 1 SCR 1021 [Norsk]. 
solution to cases of relational economic loss, he explained, "involves drawing a line that will exclude at least some people who have been undeniably injured owing to the tortfeasor's admitted failure to meet the requisite standard of care."19

Justice La Forest, however, had a problem. The duty of care, at the time, was on the authority of Kamloops $v$. Nielsen, ${ }^{20}$ and its adoption of the lax Anns test ${ }^{21}$ predicated solely on the reasonable foreseeability of harm. Application of that test would lead, for him, to an unacceptable outcome since, as he put it, "even if there were thousands of users of the bridge, the specific nature of the losses incurred would be foreseeable for all users." 22 In other words, he was concerned about indeterminate liability.

The solution, for Justice La Forest, was to invoke a policy consideration - which is possible at the second stage of the Anns/Kamloops test $^{23}$ — precluding liability for relational economic loss altogether.

Justice McLachlin, as she then was, wrote for a plurality, holding that CNR could recover in this case, although she was also concerned to identify what she saw as a "limiting device" to address "the fear of indiscriminately opening the floodgates of liability." 24

The "limiting device" she settled upon was "proximity," which for her expressed a connection between the defendant's conduct and the plaintiff's loss, by flexibly encompassing an array of factors to justify recovery in "new situations," while simultaneously limiting the scope of liability to avoid indeterminate liability. ${ }^{25}$ On the facts of Norsk, the pertinent factors — being, the relationship between the parties, what she called "physical propinquity, assumed or imposed obligations and close causal connection" — all supported a finding of proximity and the imposition of liability on the barge operator. ${ }^{26}$

Justice Stevenson wrote a separate concurrence. And I will state as someone who used to write and teach in this field - this concurrence has not received the attention it richly deserves. While agreeing with Justice McLachlin in the result, he could not support her reasoning. It was, for him, a matter of stare decisis, plain and simple. The Supreme Court had, just six years earlier, adopted Anns. And, taken seriously, Anns does not distinguish between types of loss. ${ }^{27}$

Justice Stevenson traced the exclusionary rule in cases of pure economic loss, quite correctly, to the late nineteenth century English decisions of Cattle v. The Stockton Waterworks Co. ${ }^{28}$ and Simpson v. Thomson. ${ }^{29}$ He recounted the shift of the law to a general 
(rather than categorical) principle for deciding recovery in Donoghue v. Stevenson, ${ }^{30}$ then to the line of cases that began to chip away at the exclusionary rule for recovery of claims for pure economic loss: Hedley Byrne \& Co. v. Heller \& Partners Ltd., ${ }^{31}$ for negligent misstatements; Ross v. Caunters ${ }^{32}$ for disappointed beneficiaries of negligently prepared wills; Rivtow Marine Ltd. v. Washington Iron Works ${ }^{33}$ for loss arising from breach of a duty to warn.

He then skilfully turned his mind to the line-drawing — that is, to distinguishing that which should be recoverable from that which should not. He was not enamoured of Justice McLachlin's adoption of proximity as the line-drawing device. It expressed, in his view, "a conclusion, a judgment, a result, rather than a principle." ${ }^{34}$ And Justice La Forest's concern for indeterminacy will not always arise, he pointed out. ${ }^{35}$ And, indeed, it did not even arise on the facts of this case since the plaintiff was within the contemplation of the crew operating the barge, the resulting economic loss was foreseeable, and the loss was in no way indeterminate or uncertain.

The answer, said Justice Stevenson, was to apply the law as it had already been stated by his Court. The Supreme Court adopted the Anns formulation of the duty of care in its decision of Kamloops. ${ }^{36}$ If the loss was reasonably foreseeable, it was prima facie recoverable, irrespective of the economic form such loss took.

Justice Stevenson's judgment is, in Canadian law, the most faithful expression of the duty of care framework as stated in Kamloops. ${ }^{37}$ Further, he strengthened that body of law by buttressing it with a remarkably painstaking review of relevant precedents, both from Canada and abroad. His goal was to show that the Supreme Court need not reinvent any wheels, since this same question had been asked and answered, in ways that he saw as consistent with legitimate common legal development and good judicial sense.

He acknowledged, and indeed, grappled with, the difficulties in allowing for recovery of this kind of loss, but in the end was driven to conclude that, on the law as recently stated by the Supreme Court, there is no general exclusionary rule precluding recovery of pure economic loss, including relational economic loss, in a negligence action.

It is difficult to deny, in retrospect, Justice Stevenson's wisdom in adhering to precedent in Norsk. ${ }^{38}$ Four years after Norsk, the Supreme Court abruptly changed course on the recoverability of relational economic loss, substantially adopting Justice La Forest's dissenting reasons in Norsk. ${ }^{39}$ For policy reasons, it would be generally unrecoverable, except for three recoverable so-called exceptions (which, as I have written back in the days when I could freely express my opinions on such things, are not really exceptions).

[1932] UKHL 100.

[1963] UKHL 4.

[1980] 1 Ch 297 (Ch).

[1974] SCR 1189.

Norsk, supra note 18 at 1178.

Ibid at $1179-82$.

Supra note 20.

Ibid.

Supra note 18.

Hercules Managements Ltd v Ernst \& Young, [1997] 2 SCR 165. 
And then, a mere four years after that, in Cooper v. Hobart, ${ }^{40}$ the duty of care analysis generally would be changed again by the Supreme Court, essentially adopting the "proximity" based duty formulation of Justice McLachlin in Norsk. ${ }^{41}$

All this backing-and-forthing leaves one wondering whether we should have left well enough alone. I think much of the difficulty that my Court has had in tort law over the past 30 years has been in trying to locate the golden thread - the single principle or reference point by which we can predesignate what is recoverable from what is not.

Justice Stevenson explicitly rejected the notion of a golden thread in Norsk. He said the precise limit to recovery "has vexed courts for many years and a precise limit may be impossible to express." ${ }^{\prime 2}$ For the case at bar, it sufficed simply to say that because the plaintiff was known to the defendant — that is, the plaintiff did not fall into an unascertained class of members of the public who might suffer loss as a result of negligence - the plaintiff should, in Norsk, carry the day.

In other words, just decide the case. The great principle that divides recovery from nonrecovery, if it exists, will still be out there to be found on the next swing through. Just recently, another distinguished Canadian jurist described common law reasoning as working from bottom-up — that is, from cases to principles - as opposed to civilian reasoning which, she said, works top-down - that is, from principles to cases. While there is in this description some risk of overgeneralization — for example, I think it risks obscuring the analogical quality of common law reasoning — I think that this is a fair enough description of common law reasoning. And it is entirely consistent with how Justice Stevenson saw his role in Norsk.

We live in an era in which everyone takes themselves much more seriously than they used to. And it's not just the celebrities. Long-time Supreme Court watchers will have noticed the occasional judgment that begins with grand pronouncements, made as if they were etched in mosaic tablets, so that, centuries from now, breathless students can marvel at their wisdom.

But not every case is Roncarelli v. Duplessis, ${ }^{43}$ or Donoghue v. Stevenson, ${ }^{44}$ or Salomon v. Salomon \& Co. $L t d .{ }^{45}$ In fact, very few of them are. Usually, the case is nothing more, although also nothing less, than a case that requires a decision.

And so Justice Stevenson's decisions begin with statements like: “The issue, as I analyze the matter, is whether [certain] mines and minerals passed to the Province of Alberta under the 1930 Natural Resources Transfer Agreement." ${ }^{\text {"46 }}$ Or "[t]he issues before us relate to the constitutionality of the provisions of the Criminal Code permitting certain licenced gambling and whether the non-publication of the conditions under which the licences were issued is

2001 SCC 79.

Ibid at paras 30,35 .

Norsk, supra note 18 at 1182.

[1959] SCR 121.

Supra note 30.

[1896] UKHL 1.

Canada (Director of Soldier Settlement) v Snider Estate, [1991] 2 SCR 481 at 489. 
a bar to conviction." ${ }^{47}$ Or "the issue we are to address is whether the trial judge had sufficient material before him to enable him to act upon the accused's argument that the charges were a violation of fundamental justice and a denial of the accused's right to a fair trial." ${ }^{48}$

State the issue, identify the law, apply it to the facts, and decide the case. Justice Stevenson's judgments embody the Latin motto that graces one of Edmonton's old high schools - esse quam videri — "to be, rather than to seem" - that is, be genuine, give full measure, do a good job, but don't show off.

Let me, in concluding, make three brief points about Justice Stevenson's judgments.

First point. They are models of uncommonly fine legal writing, characterized by economical, pithy, and scrupulous legal analysis. This is not accidental. They are the product of an uncommonly fine legal mind.

One of Justice Stevenson's clerks - now a leading litigator at a national firm in Toronto, and a regular customer at the Supreme Court — described him to me as the greatest black letter lawyer he'd ever known. He recalled one particularly complicated commercial case on which Justice Stevenson did not write, but where Justice Stevenson guided the author and his clerk through the complex interaction of principles involved to reach the right decision. That same clerk, I should add, reports that Justice Stevenson took very seriously the teaching role of a judge towards his clerk. Justice Stevenson was, as we know, a born teacher.

But, as a "black letter lawyer," Justice Stevenson was no mere legal technician. His dissent in Friends of the Oldman River Society $v$. Canada (Minister of Transport) ${ }^{49}$ is an example of what is now fashionably called "powerful writing," employed in that case to challenge the majority's finding that the Crown in right of Alberta is bound by the federal Navigable Waters Protection Act. ${ }^{50}$

Similarly, his decision for the majority in Canada (Director of Soldier Settlements) $v$. Snider Estate $^{51}$ combines careful legal analysis with a felicity of language in laying waste to an interpretation of the Natural Resources Transfer Agreement, ${ }^{52}$ urged upon the Supreme Court by the Soldier Settlement Board, that would have retained for the federal Crown (at the expense of the provincial Crown) all the mines and minerals from all homestead grants from the end of the First World War to 1930. On that occasion - and, so far as I was able to detect, only on that occasion - did Justice Stevenson allow himself the indulgence of expressing pleasure in having reached a particular result.

My second point about Justice Stevenson's judgments is that they cover the full range of legal subjects. As I said at the outset, I have only scratched the surface this evening. And while I also read many of his Court of Appeal decisions and trial decisions, I have narrowed 
things even further this evening by highlighting only decisions from his time at the Supreme Court. But, as I say, at all levels of court, he covered the full range, including some a little off the beaten track. In fact, just recently I had occasion to explain to one of my clerks how Justice Stevenson had given a far more understandable guide to forum non conveniens in Alberta than has been written in other provinces.

Final point. Some of you may have picked up on the fact that almost none of his reasons for judgment in the cases I chose to talk about today were majority opinions. Justice Stevenson, in a short time, wrote 20 judgments at the Supreme Court. Eight, or 40 percent of them, were either written for the Court or the majority. Twelve, or fully 60 percent of them, were dissents or concurrences. Justice Stevenson's body of work reminds us that unanimity at an appellate court is not always a virtue; nor does it mean that when an appellate court is unanimous, it is necessarily right.

More fundamentally, however, I think that Justice Stevenson's judgments illustrate the value of what Justice Dyson Heydon - a former judge of the High Court of Australia - has termed "judicial independence from within." 53 A judge's opinion contains the judiciary's account to the nation of the way in which the judges are using their vast powers. ${ }^{54}$ Justice Heydon values separate opinions, saying that they "show individual judges facing up personally to the agony of decision rather than taking the easier course of siding with the crowd." 55

Justice Stevenson's judgments reveal this very kind of courage at work. And his willingness to write separately and expose his concerns benefitted Canada as a whole.

Although we never crossed paths as colleagues, I take great pride in my shared associations with Justice Stevenson - whether it be membership on the Supreme Court, the Court of Appeal, the Court of Queen's Bench, or the Faculty of Law at the University of Alberta. But I suspect that the aspect of his legacy in which he takes particularly deep satisfaction is the Alberta Law Review - Canada's first student-run law journal. He played a major role in its establishment, served as editor-in-chief, and has remained a staunch supporter of it ever since.

And so I thought it fitting, as we celebrate the continuing contributions of the Alberta Law Review, now in its sixty-fourth year, to honour the very fine law student who oversaw its launch, and who never really left it behind during the remarkable career that followed.

May his example continue to inspire the students at today's and tomorrow's Alberta Law Review. 
[this page is intentionally blank] 